\title{
A PICTURE IS WORTH
}

\author{
Soulfood.
}

\section{BY BETH CATO}

$\mathrm{I}$ n Klatok's brief time on Earth, one thing had become clear: humans had no comprehension of the damage done by their kind.

Klatok had accepted the onerous burden of their mission with a fervent desire to deliver justice. After weeks on Earth, they were no less committed to their cause, yet mourned how the coming cataclysm would delay humanity's enlightenment. Even so, the event must happen. The immortal souls of Klatok's kind must take priority.

But first, a final stop at the grocery store.

"SUPER CELEB PREGNANT OMG," screamed the bold print of the newspaper headline. Klatok studied it as chocolate-chip cookies and thickcut potato crisps whirred down the packed conveyer belt at the checkout.

"I know, can you believe it?" asked the woman in line behind Klatok. "I think that woman's been pregnant in that same tabloid, like, three times this year."

"A remarkably fertile specimen," Klatok said, preferring neutral politeness on the sensitive subject of difficult gestations.

"Party tonight?" the cashier asked as the bagger packed up the mass of snack foods.

Klatok sidled over to pay. Their created human husk had been challenging to acclimatize to, but the ability to experience an extraordinary range of salty, sweet and umami flavours had been a delightful perk.

"A party. Yes. Of a sort," said Klatok. They noted that the woman next in line had tossed the tabloid on the conveyer. The headline still bothered Klatok as being both petty and personal. Worst of all, that paper - and every other one at the checkout thoroughly ignored the very cause of Earth's forthcoming peril.

When Klatok had arrived in human guise, they found surprisingly few newspapers and media outlets had addressed the subject of their kind. Indeed, most discussion - and the devastating photograph from Mars had proliferated on what humans termed 'the Internet'. Much of that talk doubted the truth. "It's just photo manipulation, a fake," many humans had sneered.

A fake. Klatok had

D NATURE.COM

Follow Futures:

y @NatureFutures

f go.nature.com/mtoodm struggled for days to understand how human beings could so readily doubt the image that caused profound harm. The humans' exploration module had taken a picture of a collective of Klatok's kind. To human eyes, the group resembled long, tapered humanoid flames massed together.

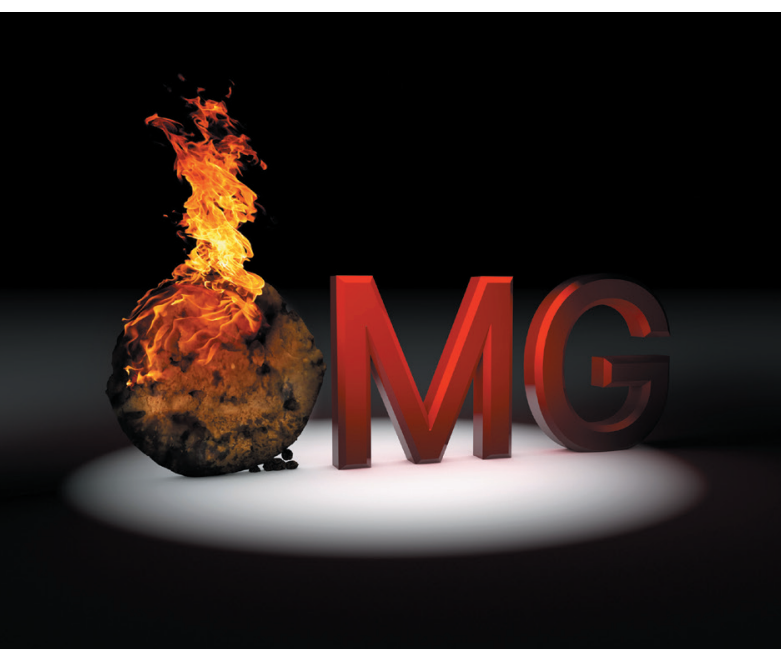

The very existence of that image fractured the souls of those depicted. As the pictures had continued to be distributed, manipulated and analysed on the Internet, their souls had continued to fragment.

Klatok felt their own soul become less as they rolled their cart beneath security cameras at the store's door.

Klatok's kind had no concept of photography or pictures. Such things were anathema. Until that indirect contact with a robotic ambassador from Earth, they had no idea their holy essences were so fragile, so susceptible to an attack that threatened to interrupt 1,000-year cycles of celebration and rebirth. The entirety of their society was unravelling, as were some of their souls, Klatok's included.

They watched a clock within their mind. Almost time.

Evening swirled the sky in pink and orange. The grid of illuminated transportation avenues spread out before their apartment balcony. Klatok sandwiched a chocolate-chip cookie between two salt and vinegar crisps, and bit down. Tartness, sweetness and saltiness exploded bliss upon their tongue.

In the same instant, the lights of human civilization blinked out.

Klatok ate more and studied the scene for posterity's sake. Although this event would help their kind to heal, they understood the grave cost that humanity would soon bear, in ignorance.
"What happened?" yelled a man on the street.

"Power's out, duh."

"My cell's not working!" came a woman's voice from a balcony below. "How widespread could this be?"

Klatok kept their counsel and ate. Bit by bit, they felt their essence become more whole as parts of their soul returned.

A sequence of electromagnetic pulses accompanied by physical assaults had just obliterated much of the planet's advanced technology. The databases that had captured shards of soul had been eliminated - for the most part. Klatok understood that some data would remain preserved. How much of that information would include lost souls, they had no way of knowing. The volume of souls bound into paper images was impossible to assess as well. Full unification for the afflicted was unlikely unless the whole planet was scorched clean, but Klatok had voted against that extreme.

Klatok's kind would face many deep spiritual and societal dilemmas in the coming cycles, but together they would endure and grow.

Humans would suffer as well. Perhaps this time of darkness and reflection would enable them also to emerge stronger and more enlightened. Maybe they would treat their Earth with more kindness, and withhold from petty cruelties along the line of SUPER CELEB PREGNANT OMG.

Loud pops and wailing sirens added music to the purpling sky. Several plumes of smoke rose to veil the first visible stars. Klatok poured crumbs into their mouth and licked their lips clean.

Perhaps by the time Klatok's kind had resolved their theological questions, humans would be ready for direct contact with an alien species. Klatok would make sure there were no cameras present this time. Their kind learnt from past foolishness; Klatok voted to preserve humanity with the hope that they, too, would learn.

Any creatures capable of creating deliciousness such as chocolate-chip cookies and salt and vinegar potato crisps had surely earned a chance at redemption.

Beth Cato resides in Arizona. She's the author of the Clockwork Dagger duology and the Blood of Earth trilogy with Harper Voyager. Her website is BethCato.com. 